\title{
Peran Perceived Discrimination Terhadap Kualitas Hidup Etnis Tionghoa di Jabodetabek
}

\section{The Role of Perceived Discrimination againts Quality of Life on Chinese Ethnic in Jabodetabek}

\author{
Safana Isnaeni Kamilia* \& Johan Satria Putra** \\ Fakultas Psikologi, Universitas YARSI, Indonesia
}

Diterima; 09 Maret 2020; Disetujui: 10 Mei 2020; Dipublish: 02 Juni 2020

**Corresponding author: E-mail: johan.satria@yarsi.ac.id

\begin{abstract}
Abstrak
Diskriminasi sering terjadi pada etnis minoritas di Indonesia, salah satunya etnis Tionghoa. Perlakuan ini dapat menyebabkan seseorang mengalami perceived discrimination, atau anggapan dan perasaan bahwa yang bersangkutan diperlakukan buruk dan tidak sama. Sejumlah penelitian terdahulu menunjukkan perceived discrimination dapat menurunkan kualitas hidup seseorang. Penelitian ini bertujuan untuk melihat peran perceived discrimination terhadap kualitas hidup pada etnis Tionghoa. Alat ukur yang digunakan adalah $P E D Q$ dan WHOQOL_BREF. Partisipan penelitian berjumlah 109 etnis Tionghoa yang bertempat tinggal di Jabodetabek dengan rentang usia 20-65 tahun, yang diambil menggunakan teknik accidental sampling. Berdasarkan hasil uji regresi, penelitian ini menunjukkan bahwa perceived discrimination memiliki peran negatif terhadap kualitas hidup pada etnis Tionghoa. Sementara itu perceived discrimination memiliki peran terhadap setiap dimensi kualitas hidup masingmasing sebesar 6,2\%, 3,8\%, 3,8\%, dan 4,3\% terhadap kualitas hidup. Diperlukan adanya intervensi kepada etnis Tionghoa yang mengalami perceived discrimination agar dapat menghilangkan pikiranpikiran negatif yang dapat mengganggu kualitas hidup dengan cara terapi kognitif, dan juga kebijakan untuk mengurangi diskriminasi itu sendiri.
\end{abstract}

Kata Kunci: Etnis Tionghoa; Kualitas Hidup; Perceived Discrimination.

\begin{abstract}
Discrimination often occurs in ethnic minorities in Indonesia, one of them is the ethnic Chinese. Meanwhile, discrimination makes a person experience perceived discrimination which will result in a lower quality of life. This study aims to look at the role of perceived discrimination on the quality of life of ethnic Chinese. This research uses PEDQ and WHOQOL_BREF. Participants in this study were 109 ethnic Chinese living in JABODETABEK aged 20-65 years with accidental sampling techniques. The results obtained in this study are perceived discrimination contributing to the quality of life of ethnic Chinese by 6.2\%, 3.8\%, 3.8\%, and 4.3\%. The implications in this study are as input to ethnic Chinese who often experience perceived discrimination to try to eliminate negative thoughts that can disrupt quality of life by means of cognitive therapy.
\end{abstract}

Keywords: Chinese Ethnic, Perceived Discrimination, Quality of Life

How to Cite: Kamilia, S.I., \& Putra, J.S. (2020), Peran Perceived Discrimination Terhadap Kualitas Hidup Etnis Tionghoa di Jabodetabek, Jurnal Diversita, 6 (1): 122-132. 


\section{PENDAHULUAN}

Diskriminasi etnis merupakan salah satu diskriminasi yang cenderung sensitif dan menjadi potensi terhadap adanya konflik di Indonesia (Armiwulan, 2015). Diskriminasi etnis juga sering terjadi pada etnis-etnis minoritas, di mana salah satu etnis minoritas yang mendapatkan perlakuan diskriminasi di Indonesia adalah etnis Tionghoa (Juditha, 2015). Survei yang dilakukan oleh Wahid Foundation (Aziz, 2018) pada tahun 2017 menyatakan bahwa etnis Tionghoa merupakan kelompok yang kurang disukai, dimana rasa kurang menyukai pada etnis Tionghoa dikatakan setara dengan rasa kurang menyukai terhadap non-muslim, komunis, LGBT, dan kelompok Yahudi. Etnis Tionghoa dianggap golongan non pribumi karena memiliki percampuran bahasa dan budaya serta datang ke Indonesia setelah terbentuknya suku-suku di Indonesia. Hal ini membuat orang-orang dengan etnis Tionghoa mengubah nama Tionghoanya menjadi nama pribumi (Christine, 2017).

Etnis Tionghoa di Indonesia mengalami diskriminasi yang sudah terjadi dari sejak masa Vereenigde Oostindische Compagnie (VOC), orde lama, orde baru, hingga saat ini (Aziz, 2018). Saat ini etnis Tionghoa pun mengalami diskriminasi seperti tidak disukai atau tidak diterima dalam pekerjaan atau jabatan dikarenakan etnis yang dimilikinya (Rochmi, dalam Yulianto, 2016). Kasus-kasus yang peneliti paparkan tersebut menunjukan banyaknya diskriminasi terhadap etnis Tionghoa di kota-kota besar seperti Jabodetabek.
Definisi dari diskriminasi itu sendiri ialah perlakuan secara berbeda atau tidak sama oleh kelompok atau lingkungannya dan merupakan pengalaman yang dapat membuat seseorang mengalami perceived discrimination (Levine \& Hogg, 2010; Yang, Chen, Choi, \& Kurtulus, 2018). Menurut Sutin, Stephan, Carretta, dan Terracciano (2015), perceived discrimination adalah anggapan diperlakukan tidak adil dikarenakan karakteristik pribadi. Penelitian ini akan menggunakan definisi perceived discrimination yang dikemukakan oleh Mayor et.al. (2002).

Terdapat beberapa penelitian mengenai perceived discrimination, dimana perceived discrimination berperan terhadap kondisi kesehatan fisik yang buruk (Contrada, Ashmore, Gary, Coups, Egeth, Sewell, Ewell, \& Goyal, 2001; Sutin, Stephan, Carretta, \& Terracciano, 2015; Flores, Tschann, Dimas, Bachen, Pasch, \& Groat, 2008). Selain kesehatan fisik, perceived discrimination juga berperan secara psikologis yaitu membuat kesehatan mental menjadi buruk, adanya gejala depresi, mempengaruhi harga diri, stres, dan mempengaruhi keyakinan nilai serta pentingnya ras individu (Fischer dan Shaw, dalam Cassidy dkk, 2004; Keshler, Mickelson, \& Williams, 1999; Thoits, dalam Jang, Chiriboga, \& Small, 2008; Narra \& Claudius, 2013; Contrada et.al., 2001; Flores, et.al., 2008; Major, Kaiser, O’Brien \& McCoy, 2007; Sellers, Caldwell, Cone, \& Zimmerman, 2003). Di samping itu, perceived discrimination juga mempengaruhi kondisi sosial seperti membuat adanya antisocial behaviors (Rivera, Lopez, Guarnaccia, Ramirez, Canino, \& Bird, 2010). Perceived 
discrimination juga membuat kondisi lingkungan individu menjadi buruk seperti menjaga jarak dengan lingkungan dan tidak menghiraukan lingkungan (Basar, Oz, \& Karaya, 2016; Sinulingga, Dhiozandi, Meriska, Mutia, Adjisukmo, \& Dahesihsari, 2015; Juditha, 2015).

Penelitian yang dilakukan oleh Basar, Öz, dan Karakaya (2016) menemukan bahwa perceived discrimination secara signifikan memprediksi kualitas hidup yang buruk dalam domain kualitas hidup sosial dan lingkungan karena dukungan sosial maupun lingkungan dapat mempengaruhi individu dalam menyikapi perceived discrimination dimana perceived discrimination yang dirasakan akan berbeda jika dialami sendiri daripada bersama-sama atau berkelompok. Penelitian yang dilakukan oleh Hasan, Alviany, Clarissa, dan Kusuma (2017) menyatakan bahwa perceived discrimination secara signifikan terkait dengan kualitas hidup seseorang, dan diskriminasi yang terjadi pada individu membuat kualitas hidupnya rendah. Penelitian yang dilakukan oleh Logie, Wang, Lacombe-Ducana, Wagner, Kaida, Conway, Websterd, Pokomandye, dan Loutfy (2018) menunjukkan bahwa perceived discrimination mempengaruhi kualitas hidup orang Afrika-Amerika yang keturunan Afrika, karena orang-orang tersebut memiliki keterbatasan dalam melakukan perlawanan ketika diperlakuan buruk yang disebabkan oleh ras yang dimiliki.

Berdasarkan pemaparan di atas dapat dilihat bahwa perceived discrimination memiliki peran terhadap kualitas hidup. Kualitas hidup merupakan aspek penting untuk diteliti karena dapat mempengaruhi sikap individu dalam kehidupannya. Apabila kualitas hidup rendah karena disebabkan oleh perceived discrimination maka individu merasa tidak nyaman dalam kehidupannya serta dapat menghambat kehidupan individu. Selain itu, kualitas hidup juga merupakan konsep luas yang mencakup kesejahteraan individu dalam berbagai domain (Fourianalistyawati, Listiyandini, dan Fitriana, 2016).

Dengan demikian, tujuan penelitian ini adalah mengetahui peran perceived discrimination terhadap kualitas hidup etnis Tionghoa. Penelitian ini diharapkan dapat menambah informasi mengenai penelitian pada etnis Tionghoa, perceived discrimination, dan kualitas hidup, khususnya dalam studi psikologi sosial. Hasil penelitian ini juga dapat dijadikan landasan pembuatan program untuk etnis Tionghoa, terkait perceived discrimination dan dampaknya.

\section{METODE PENELITIAN}

Sampel dalam penelitian ini ialah 109 partisipan etnis Tionghoa yang tinggal di JABODETABEK dengan usia dewasa muda dan dewasa tengah. arakteristik sampel dalam penelitian ini adalah etnis Tionghoa yang berusia dewasa awal (20 40 tahun) dan dewasa tengah (40 - 65 tahun) dengan menggunakan teknik pengumpulan data accidental sampling.

Penelitian ini menggunakan sampel dewasa dikarenakan semakin bertambahnya usia, emosi akan menjadi lebih matang dan terkendali (Benokraitis, dalam Khairani \& Putri, 2008). Menurut Papalia dan Feldman (2014) usia dewasa muda dimulai dari usia 20 - 40 tahun dan 
dewasa tengah dimulai dari usia $40-65$ tahun.

Alat ukur yang digunakan untuk mengukur perceived discrimination adalah Perceived Ethnic Discrimination Questionnaire (PEDQ) yaitu alat ukur unidimensional yang diciptakan oleh Contrada, Ashmore, Gary, Coups, Egeth, Sewell, Ewell, dan Goyal (2001) 22 item dengan nilai reliabilitas adalah $\mathrm{p}>0,7$. Kuesioner ini menggunakan skala likert 7 poin, mulai dari 1 (tidak pernah) sampai 7 (sangat sering) untuk menunjukkan seberapa sering pada 3 bulan terakhir semua bentuk diskriminasi dialami oleh subjek.

Alat ukur yang digunakan untuk mengukur kualitas hidup dalam penelitian ini ialah alat ukur World Health Organization Quality of Life ScaleAbbreviated form (WHOQOL-BREF) yaitu alat ukur multidimensi yang diadaptasi oleh Purba, Hunfeld, Iskandarsyah, Fitriana, Sadarjoen, Passchier, dan Busschbach (2018) dan terdiri dari 26 aitem. Adapun reliabilitas dalam alat ukur ini ialah $\mathrm{p}>0,7$.

Analisis data menggunakan uji regresi untuk menguji hipotesis penelitian, yaitu peran perceived discrimination terhadap kualitas hidup. Variabel prediktor dalam penelitian ini adalah perceived discrimination, dengan definisi operasional yaitu anggapan dan perasaan individu bahwa ia diperlakukan secara tidak sama. Sedangkan variabel kriteria dalam penelitian ini adalah kualitas hidup, dengan definisi operasional persepsi individu mengenai dirinya dalam kehidupannya pada dimensi kesehatan fisik, psikologis, hubungan sosial, dan lingkungan.

\section{HASIL DAN PEMBAHASAN}

Jumlah responden yang diperoleh dalam penelitian ini sebanyak 109 responden. Mayoritas responden berusia 20-40 tahun dengan presentase 74,3\%, berjenis kelamin laki-laki (56\%), berdomisili di DKI Jakarta, pendidikan terakhir di bawah SMA, serta bertempat tinggal dan bekerja di lingkungan yang mayoritas bukan etnis Tionghoa (55\% dan $61 \%)$.

Uji korelasi dilakukan untuk mengetahui hubungan antara perceived discrimination dan kualitas hidup etnis Tionghoa dengan menggunakan teknik Pearson Product Moment pada variabel perceived discrimination dengan kualitas hidup dimensi fisik, psikologis, dan lingkungan karena memiliki data yang terdistribusi normal. Kemudian penelitian ini menggunakan Spearman Rank untuk variabel perceived discrimination dengan kualitas hidup dimensi sosial karena memiliki data yang tidak terdistribusi normal.

Hasil uji korelasi lebih lanjut dapat dilihat pada Tabel 1. Berdasarkan data pada tabel 1 terlihat bahwa perceived discrimination memiliki korelasi degan kualitas hidup dimensi kesehatan fisik, psikologis, hubungan sosial, dan lingkungan karena signifikansi pada masing-masing variabel di bawah $<0,05$, dengan nilai korelasi negatif. 
Tabel 1. Hasil Uji Korelasi

\begin{tabular}{|c|c|c|}
\hline & $\mathrm{R}$ & Sig. \\
\hline $\begin{array}{l}\text { Perceived } \\
\text { discrimination dan } \\
\text { Kualitas Hidup (Fisik) }\end{array}$ & $-0,249$ & $0,009 * *$ \\
\hline $\begin{array}{lr}\begin{array}{l}\text { Perceived } \\
\text { discrimination }\end{array} & \text { dan } \\
\text { Kualitas } & \text { Hidup } \\
\text { (Psikologis) } & \\
\end{array}$ & $-0,196$ & $0,041^{*}$ \\
\hline $\begin{array}{lr}\text { Perceived } & \\
\text { discrimination } & \text { dan } \\
\text { Kualitas } & \text { Hidup } \\
\text { (Sosial) } & \\
\end{array}$ & $-0,316$ & $0,001^{* *}$ \\
\hline $\begin{array}{lr}\text { Perceived } & \\
\text { discrimination } & \text { dan } \\
\text { Kualitas } & \text { Hidup } \\
\text { (Lingkungan) } & \end{array}$ & $-0,207$ & $0,031^{*}$ \\
\hline
\end{tabular}

Uji hipotesis dilakukan untuk melihat apakah variabel $\mathrm{X}$ memiliki peran signifikan terhadap variabel Y. Pada penelitian, ini peneliti ingin melihat signifikansi peran perceived discrimiation terhadap kualitas hidup etnis Tionghoa. Uji hipotesis dilakukan dengan analisis regresi sederhana. Adapun rumus persamaan regresi yakni $\mathrm{Y}=\mathrm{a}+\mathrm{b} \mathrm{X}$. Hasil uji regresi dapat dilihat pada Tabel 2 .

Tabel 2. Hasil Uji Regresi

\begin{tabular}{llll}
\hline & R Square & Sig & $\begin{array}{l}\text { Persamaan } \\
\text { Regresi }\end{array}$ \\
\hline $\begin{array}{l}\text { Perceived } \\
\text { discrimination } \\
\text { dan Kualitas }\end{array}$ & 0,062 & $0,009^{*}$ & $\begin{array}{l}\text { Y }=4,124- \\
0,249 X\end{array}$ \\
Hidup (Fisik) & & & \\
\hline $\begin{array}{l}\text { Perceived } \\
\text { discrimination }\end{array}$ & 0,038 & $0,041^{*}$ & Y $=3,935-$ \\
dan Kualitas & & & $0,196 \mathrm{X}$ \\
$\begin{array}{l}\text { Hidup Kup } \\
\text { (Psikologis) }\end{array}$ & & & \\
\hline $\begin{array}{l}\text { Perceived } \\
\text { discrimination }\end{array}$ & 0,038 & $0,043^{*}$ & $Y=3,850-$ \\
dan Kualitas & & & $0,194 \mathrm{X}$ \\
Hidup (Sosial) & & & \\
\hline $\begin{array}{l}\text { Perceived } \\
\text { discrimination }\end{array}$ & 0,043 & $0,031^{*}$ & Y $=3,769-$ \\
dan Kualitas & & & $0,207 X$ \\
Hidup & & \\
(Lingkungan) & & & \\
\hline
\end{tabular}

Berdasarkan data pada tabel 2 terlihat bahwa hasil uji regresi perceived discrimination berperan signifikan terhadap kualitas hidup pada dimensi kesehatan fisik $(F=7,100 p<0,05)$. Nilai koefisien determinasi yang diperoleh adalah 0,062 . Nilai koefisien determinasi menunjukan besaran peran dalam persen yakni 6,2\%. Hal ini dapat dikatakan bahwa perceived discrimination berperan signifikan terhadap kualitas hidup pada dimensi kesehatan fisik etnis Tionghoa sebesar $\quad 6,2 \%$ dan $93,8 \%$ lainnya dipengaruhi oleh faktor lain. Dapat disimpulkan bahwa hasil uji hipotesis 1 yakni terdapat peran signifikan dari perceived discrimination terhadap kualitas hidup dimensi kesehatan fisik etnis Tionghoa diterima. Berdasarkan tabel di atas, perolehan persamaan linear ialah $Y=$ 4,124-0,249X. Hal ini menunjukan bahwa setiap bertambahnya 1 nilai pada perceived discrimination, maka nilai pada kualitas hidup dalam dimensi kesehatan fisik akan berkurang sebesar 0,249.

Hasil uji regresi perceived discrimination berperan signifikan terhadap kualitas hidup pada dimensi psikologis $\quad(F=4,284 \quad p<0,05) . \quad$ Nilai koefisien determinasi yang diperoleh adalah 0,038 . Nilai koefisien determinasi menunjukan besaran peran dalam persen yakni 3,8\%. Hal ini dapat dikatakan bahwa perceived discrimination berperan signifikan terhadap kualitas hidup pada dimensi psikologis etnis Tionghoa sebesar $-3,8 \%$ dan $96,2 \%$ lainnya dipengaruhi oleh faktor lain.

Dapat disimpulkan bahwa hasil uji hipotesis 2 yakni terdapat peran signifikan dari perceived discrimination terhadap kualitas hidup dimensi psikologis etnis 
Tionghoa diterima. Berdasarkan tabel di atas, perolehan persamaan linear ialah $\mathrm{Y}=$ 3,935-0,196X. Hal ini menunjukan bahwa setiap bertambahnya 1 nilai pada perceived discrimination, maka nilai pada kualitas hidup dalam dimensi psikologis akan berkurang sebesar 0,196.

Hasil uji regresi perceived discrimination berperan signifikan terhadap kualitas hidup pada dimensi hubungan sosial $(F=4,185 \mathrm{p}<0,05)$. Nilai koefisien determinasi yang diperoleh 0,038 . Nilai koefisien determinasi menunjukan besaran peran dalam persen yakni 3,8\%. Hal ini dapat dikatakan bahwa perceived discrimination berperan signifikan terhadap kualitas hidup pada dimensi hubungan sosial etnis Tionghoa sebesar $\quad 3,8 \%$ dan $96,2 \%$ lainnya dipengaruhi oleh faktor lain.

Dapat disimpulkan bahwa hasil uji hipotesis 3 yakni terdapat peran signifikan dari perceived discrimination terhadap kualitas hidup dimensi hubungan sosial etnis Tionghoa diterima. Berdasarkan tabel di atas, perolehan persamaan linear ialah $\mathrm{Y}=3,850-0,194 \mathrm{X}$. Hal ini menunjukan bahwa setiap bertambahnya 1 nilai pada perceived discrimination, maka nilai pada kualitas hidup dalam dimensi hubungan sosial akan berkurang sebesar 0,194 .

Hasil uji regresi perceived discrimination berperan signifikan terhadap kualitas hidup pada dimensi lingkungan $(F=4,775 p \quad<0,05)$. Nilai koefisien determinasi yang diperoleh adalah 0,043 . Nilai koefisien determinasi menunjukan besaran peran dalam persen yakni 4,3\%. Hal ini dapat dikatakan bahwa perceived discrimination berperan signifikan terhadap kualitas hidup pada dimensi lingkungan etnis Tionghoa sebesar $\quad 4,3 \%$ dan $95,7 \%$ lainnya dipengaruhi oleh faktor lain.

Hal tersebut dapat disimpulkan bahwa hasil uji hipotesis 4 yakni terdapat peran signifikan perceived discrimination terhadap kualitas hidup dimensi lingkungan etnis Tionghoa diterima. Berdasarkan tabel di atas, perolehan persamaan linear ialah $Y=3,769-0,207 X$. Hal ini menunjukan bahwa setiap bertambahnya 1 nilai pada perceived discrimination, maka nilai pada kualitas hidup dalam dimensi lingkungan akan berkurang sebesar 0,207.

Penelitian ini bertujuan untuk mengetahui peran perceived discrimination terhadap kualitas hidup etnis Tionghoa di Jabodetabek. Hasil penelitian menunjukan bahwa perceived discrimination berperan secara signifikan terhadap kualitas hidup pada dimensi fisik $\left(\mathrm{p}=0,009^{*} R\right.$-squared $=$ 0,062 ). Variabel perceived discrimination terhadap kualitas hidup dimensi kesehatan fisik etnis Tionghoa memiliki peran sebesar 6,2\% dan 93,8\% lainnya dipengaruhi oleh faktor lain. Adapun hasil persamaan regresi yang diperoleh ialah $\mathrm{Y}$ $=4,124-0,249 \mathrm{X}$. Hal ini menunjukan bahwa setiap bertambahnya 1 nilai pada perceived discrimination, maka nilai pada kualitas hidup dalam dimensi kesehatan fisik akan berkurang sebesar 0,249.

Hasil penelitian ini menunjukkan apabila seseorang mengalami perceived discrimination, maka hal tersebut dapat berdampak reaktif pada kesehatan fisiknya. Adapun penelitian lain yang menemukan bahwa perceived discrimination berdampak negatif terhadap kesehatan fisik seperti menyababkan hipertensi, kanker 
payudara, obesitas, tekanan darah tinggi, dan penggunaan zat (Williams \& Mohammed, dalam Pascoe \& Richman, 2009). Hal ini disebabkan karena perceived discrimination membuat Creaktif protein meningkat dan tekanan darah dapat menjadi sangat naik atau sangat turun (Sutin dkk, 2015). C-reaktif protein merupakan protein fase akut, dan apabila C-reaktif protein tinggi maka menyebabkan resiko terjadinya penyakit jantung koroner, aterosklerosis, diabetes mellitus tipe 2, dan kanker (Nisa, 2016). Sementara itu, jika tekananan darah tinggi ataupun rendah dapat menyebabkan jiwa terancam seperti kematian mendadak (Lintang, dalam Sukadiono \& Fauzan, n.d.; Herwati \& Sartika, 2013). Oleh karena itu hal tersebut dapat membuat kesehatan fisik menurun jika mengalami perceived discrimination.

Perceived discrimination berperan secara signifikan terhadap kualitas hidup pada dimensi psikologis ( $\mathrm{p}=0,041^{*} R$ squared $=0,038)$. Variabel perceived discrimination terhadap kualitas hidup pada dimensi psikologis etnis Tionghoa memiliki peran sebesar 3,8\% dan 96,2\% lainnya dipengaruhi oleh faktor lain. Adapun hasil persamaan regresi yang diperoleh ialah $\mathrm{Y}=3,935-0,196 \mathrm{X}$. Hal ini menunjukan bahwa setiap bertambahnya 1 nilai pada perceived discrimination, maka nilai pada kualitas hidup dalam dimensi psikologis akan berkurang sebesar 0,196. Hasil penelitian menunjukkan apabila seseorang mengalami perceived discrimination, maka hal tersebut dapat berdampak reaktif pada kondisi psikologisnya.

Adapun penelitian lain yang menemukan bahwa perceived discrimination berdampak negatif terhadap kondisi psikologis seperti menyebabkan tekanan psikologis (Sellers $\mathrm{dkk}, 2003)$, stress (Sellers dkk, 2003), gejala depresi (Contrada dkk, 2001), mempengaruhi harga diri (Major dkk, 2007), dan perubahan suasana hati yang negatif (Fernandez-Ballesteros dkk, 2017). Namun, ketika perceived discrimination membuat suasana hati seseorang menjadi turun ataupun depresi maka seseorang tersebut rentan untuk melakukan bunuh diri, terkena gangguan pola tidur, gangguan pola makan, berperilaku merusak, memiliki perasaan bersalah, sering menyendiri dan menangis (Lubis, 2009). Oleh karena itu, kondisi psikologis seseorang dapat menurun jika mengalami perceived discrimination.

Perceived discrimination berperan secara signifikan terhadap kualitas hidup pada dimensi hubungan sosial $\left(\mathrm{p}=0,043^{*}\right.$ $R$-squared $=0,038)$. Variabel perceived discrimination terhadap kualitas hidup pada dimensi hubungan sosial etnis Tionghoa memiliki peran sebesar 3,8\% dan 96,2\% lainnya dipengaruhi oleh faktor lain. Adapun hasil persamaan regresi yang diperoleh ialah Y = 3,850-0,194X. Hal ini menunjukan bahwa setiap bertambahnya 1 nilai pada perceived discrimination, maka nilai pada kualitas hidup dalam dimensi hubungan sosial akan berkurang sebesar 0,194 . Hasil penelitian menunjukkan apabila seseorang mengalami perceived discrimination, maka hal tersebut dapat berdampak reaktif pada hubungan sosialnya.

\begin{tabular}{|c|c|}
\hline $\begin{array}{l}\text { Adapun } \\
\text { temukan } \\
\text { rimination }\end{array}$ & $\begin{array}{l}\text { penelitian } \\
\text { bahwa } \\
\text { berdampak }\end{array}$ \\
\hline lap & sosi \\
\hline
\end{tabular}


memunculkan hambatan dalam berkomunikasi (Sinulingga dkk, 2015; Juditha, 2015), menghidari berkomunikasi (Sinulingga dkk, 2015; Juditha, 2015), dan hanya berkomunikasi dengan kelompok yang memiliki kesamaan (Sinulingga dkk, 2015). Sementara itu, hal tersebut dapat menyebabkan adanya kesalah pahaman yang dapat menimbulkan konflik (Anwar, 2015). Oleh karena itu hubungan sosial menjadi rendah jika mengalami perceived discrimination.

Perceived discrimination berperan secara signifikan terhadap kualitas hidup pada dimensi lingkungan $\left(\mathrm{p}=0,031^{*} R\right.$ squared $=0,043)$. Variabel perceived discrimination terhadap kualitas hidup pada dimensi lingkungan etnis Tionghoa memiliki peran sebesar 4,3\% dan 95,7\% lainnya dipengaruhi oleh faktor lain.

Adapun hasil persamaan regresi yang diperoleh ialah $Y=3,769-0,207 X$. Hal ini menunjukan bahwa setiap bertambahnya 1 nilai pada perceived discrimination, maka nilai pada kualitas hidup dalam dimensi lingkungan akan berkurang sebesar 0,207 . Hasil penelitian menunjukkan apabila seseorang yang mengalami perceived discrimination, maka hal tersebut dapat berdampak reaktif pada lingkungannya seperti merasa terisolasi, merasa tidak aman, merasa tidak bebas (Islami dan Kuncoro, 2017), dan tidak menghiraukan lingkungan (Juditha, 2015). Hal ini disebabkan karena lingkungan merupakan salah satu aspek yang mempengaruhi perilaku (Nuqul, 2005). Maka dari itu aspek lingkungan seseorang menjadi terganggu jika mengalami perceived discrimination.

Berdasarkan pemaparan diatas dapat disimpulkan bahwa perceived discrimination dapat menurunkan kualitas hidup. Hal ini sejalan dengan penelitian Basar dkk (2016) bahwa perceived discrimination memprediksi kualitas hidup yang buruk. Selain itu, penelitian ini juga sejalan dengan penelitian Hasan dkk (2017) bahwa perceived discrimination secara signifikan terkait dengan kualitas hidup seseorang dan diskriminasi yang terjadi membuat kualitas hidup menjadi rendah. Penelitian yang dilakukan oleh Epel, Kaplan, dan Moran (2010) menyatakan bahwa ketika etnis minoritas merasakan didiskriminasi maka kepuasan hidupnya menjadi rendah. Kemudian, penelitian ini juga menggunakan analisis tambahan uji beda. Hasil uji beda yang telah dilakukan menunjukan bahwa tidak terdapat perbedaan antara dimensidimensi kualitas hidup terhadap variabel demografi jenis Tionghoa.

Secara keseluruhan, penelitian ini memiliki hambatan seperti pada saat melakukan uji coba alat ukur kualitas hidup, terdapat nilai analisa aitem yang rendah pada dimensi psikologis. Kemudian, limitasi penelitian ini adalah memiliki data yang tidak terdistribusi normal pada variabel perceived discrimination terhadap kualitas hidup dimensi hubungan sosial, sehingga hasil penelitian antar variabel tersebut tidak dapat digeneralisasikan kepada populasi lain. Selain itu, penelitian ini memiliki implikasi yakni sebagai masukan kepada etnis Tionghoa yang sering mengalami perceived discrimination untuk berusaha menghilangkan pikiran-pikiran negatif yang dapat mengganggu kualitas hidup, dan untuk membantu cara berpikir dengan baik dapat dibantu oleh terapi kognitif. Namun, penelitian ini juga 
memiliki kelebihan seperti mendukung semua hipotesis penelitian.

\section{SIMPULAN}

Berdasarkan analisis yang dilakukan, dapat disimpulkan bahwa hipotesis dalam penelitian ini diterima yakni terdapat peran signifikan dari perceived discrimination terhadap kualitas hidup etnis Tionghoa pada dimensi kesehatan fisik, psikologis, hubungan sosial, dan lingkungan. Artinya, ketika seseorang mengalami perceived discrimination maka akan membuat kualitas hidupnya menjadi rendah. Semakin tinggi perceived discrimination yang dialami maka semakin rendah kualitas hidup yang dimiliki, dan sebaliknya.

Penelitian ini juga membuktikan bahwa terdapat peran perceived discrimination dalam kualitas hidup etnis Tionghoa dalam pandangan Islam. Artinya, ketika seseorang mengalami perceived discrimination (buruk sangka) maka akan membuat konsep dimensi-dimensi kualitas hidup (kebugaran jasmani, psikologis, hablumminannas, melestarikan lingkungan) menjadi terganggu.

Penelitian selanjutnya diharapkan untuk menambah jumlah sampel penelitian jika memiliki analisa aitem yang rendah pada saat melakukan uji coba alat ukur.

Individu yang berasal dari etnis Tionghoa disarankan untuk mengikuti terapi kognitif misalnya CBT. Lebih lanjut Lembaga Swadaya Masyarakat (LSM), dapat mengadakan penyuluhan mengenai cara dalam mengatasi perceived discrimination.

\section{DAFTAR PUSTAKA}

Anwar, C. (2015). Manajemen konflik untuk menciptakan komunikasi yang efektif: studi kasus di departemen purchasing pt. Sumi Rubber Indonesia. Jurnal Interaksi. 4 (2), $148-157$.

Armiwulan, H. (2015). Diskriminasi rasial dan etnis sebagai persoalan hukum dan hak asasi manusia. MMH. 44 (4), 493-502.

Aziz, M. (2018). Tionghoa, antara sasaran kebencian dan ketimpangan sosial. Diunduh di https://nasional.kompas.com/read/2018/o2/ 22/14163721/tionghoa-antara-sasarankebencian-dan-ketimpangan-sosial pada tanggal 28 September

Başar, K., Öz, G., \& Karakaya, J. (2016). Perceived discrimination, social support, and quality of life in gender dysphoria. The Journal of Sexual Medicine. 13 (7), 1133-1141.

Cassidy, C., O'Connor, R.C., Howe, C. \& Warden, D. (2004). Perceived discrimination and psychological distress: The role of personal and ethnic self esteem. Journal of Counseling Psychology. 51, 329-339.

Christine, Y. D. (2017). Tidak ada "Pribumi" di Indonesia. Diunduh di https://www.kompasiana.com/yolandadc/5 8fe1951d57a619664ae1728/tidak-adapribumi-di-indonesia?page $=1$ pada tanggal 1 Juli 2019

Contrada, R. J., Ashmore, R. D., Gary, M. L., Coups, E., Egeth, J. D., Sewell, A., Ewell, K., \& Goyal, T. M. (2001). Measures of ethnicity-related stress: Psychometric properties, ethnic group differences, and associations with well-being. Journal of Applied Social Psychology. 31 (9), 1775-1820.

Epel, O. B., Kaplan G., \& Moran, M. (2010). Perceived discrimination and health-related quality of life among Arabs and Jews in Israel: A population-based survey. BMC Public Health. 10, 282.

Flores, E., Tschann, J. M., Dimas, J. M., Bachen, E. A., Pasch, L. A., \& de Groat, C. L. (2008). Perceived discrimination, perceived stress, and mental and physical health among mexican-origin adults. Hispanic Journal of Behavioral Sciences. 30 (4), 401-424.

Fourianalistyawati, E., Listiyandini, R. A., \& Fitriana, T. S. (2016). Hubungan mindfulness dan kualitas hidup orang dewasa. Prosiding Forum Ilmiah Psikologi Indonesia. (1), 1-12.

Hasan, S., Alviany, Y., Clarissa, C., \& Kusuma, S. S. (2017). High perceived discrimination and 
no family support increase risk of poor quality of life in gender dysphoria. Universa Medicina. 36 (3), 187-196.

Islami, D.A.N., \& Kuncoro, J. (2017). Agreeableness dan konformitas dengan kebutuhan rasa aman pada anggota komunitas punk di Jawa Tengah. Proyeksi. 12 (2), 87 - 94.

Jang, Y., Chiriboga, D. A., \& Small, B.J. (2008). Perceived discrimination and psychological well-being: The mediating and moderating role of sense of control. NIH Public Access. 66 (3): 213-227.

Juditha, C. (2015). Stereotip dan prasangka dalam konflik etnis Tionghoa dan Bugis Makassar. Jurnal Ilmu Komunikasi. 12 (1).

Kaiser, C. R., \& Major, B. (2006). A social psychological perspective on perceiving and reporting discrimination. Law \& Social Inquiry. 31 (4), 801-830.

Kessler R., Mickelson K., \& Williams D. (1999). The prevalence, distribution, and mental health correlates of perceived discrimination in the United States. Journal of Health and Social Behavior. 40, 208-230.

Khairani, R. \& Putri, D. E. (2008). Kematangan emosi pada pria dan wanita yang menikah muda. Jurnal Psikologi. 1 (2).

Larasati, T. (2012). Kualitas hidup pada wanita yang sudah memasuki masa menopause. Jurnal Fakultas Psikologi Universitas Gunadarma.

Levine, J. M., \& Hogg, M. A. (2010). Encyclopedia of group processes and intergroup relations. California: SAGE.

Logie, C.H., Wang, Y., Lacombe-Ducana, A., Wagner, A.C., Kaida, A., Conway, T., Websterd, K., Pokomandye, A. D., \& Loutfy, M. R. (2018). HIV-related stigma, racial discrimination, and gender discrimination: Pathways to physical and mental healthrelated quality of life among a national cohort of women living with HIV. Preventive Medicine. 107, 36-44.

Lubis, N. L. (2009). Depresi Tinjauan Psikologis. Jakarta: Kencana.

Major, B., Kaiser, C. R., O’Brien, L. T., \& McCoy, S. K. (2007). Perceived discrimination as worldview threat or worldview confirmation: implications for self-esteem. Journal of Personality and Social Psychology. 92 (6), 1068-1086.

Narra, P. T., \& Claudius, M. (2013). Perceived discrimination and depressive symptoms among immigrant-origin adolescents.
American Psychological Association. 19 (3), 257-269.

Nisa, H. (2016). Peran c-reactive protein untuk menimbulkan risiko penyakit. JMI. 13 (1), 18.

Nuqul, F. L. (2005). Pengaruh lingkungan terhadap perilaku manusia:studi terhadap perilaku penonton bioskop. Nitro Pdf Professional. (n.d.)

Papalia, D. E., \& Feldman, R. D. (Eds.). (2014). Menyelami perkembangan manusia. Jakarta: Salemba Humanika.

Pascoe, E. A., \& Richman, L. S. (2009). Perceived discrimination and health: A meta-analytic review. American Psychological Association. 135 (4), 531-554.

Purba, F. D., Hunfeld, J. A. M., Iskandarsyah, A., Fitriana, T. S., Sadarjoen, S. S., Passchier, J., \& Busschbach, J. J. V. (2018). Quality of life of the Indonesian general population: Testretest reliability and population norms of the EQ-5D-5L and WHOQOL-BREF. PloS ONE. 13 (5), 1-20.

Rivera, F., Lopez, I., Guarnaccia, P., Ramirez, R., Canino, G., \& Bird, H. (2010). Perceived discrimination and antisocial behaviors in PuertoRican Children. J Immigrant Minority Health. 13 (3), 453-61.

Sellers, R. M., Caldwell, C. H., Cone, K. H. S., \& Zimmerman, M. A. (2003). Racial identity, racial discrimination, perceived stress, and psychological distress among African American young adults. Journal of Health and Social Behavior. 1 (43), 302-317.

Sinulingga, C. E., Dhiozandi, H., Meriska, I., Mutia, R., Adjisukmo, C., \& Dahesihsari, R. (2015). Gambaran pengalaman diskriminasi terhadap individu LGBTQIA+ yang tergabung dalam organisasi “S”. Jurnal Ilmiah Psikologi MANASA. 4 (2), 74-89.

Sukadiono., \& Fauzan, A. (n.d.). Peningkatan tekanan darah pada penderita hipotensi dengan penerapan jalan kaki interval. Jurnal Ilmu Kesehatan. (n.d.)

Sutin, A. R., Stephan, Y., Carretta, H., \& Terracciano, A. (2015). Perceived discrimination and physical, cognitive, and emotional health in older adulthood. NIH Public Access. 23 (2), 171-179.

World Health Organization. (1996). WHOQOLBREF introduction, administration, scoring and generic version of the assessment. Geneva: UN.

Yang, T.-C., Chen, I.-C., Choi, S., \& Kurtulus, A. (2018). Linking perceived discrimination 
Jurnal Diversita, 6 (1) Juni 2020: 122-132.

during adolescence to health during midadulthood: Self-esteem and risk-behavior mechanisms. Social Science \& Medicine. 232, 434-443.

Yulianto, M. A. (2016). Penerimaan penonton terhadap diskriminasi etnis Tionghoa dalam film: "Ngenest". Jurnal EKomunikasi. 4 (1). 